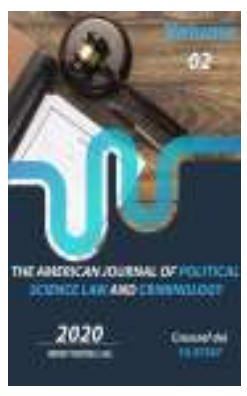

\title{
Overview Of Legislation Of Uzbekistan On The Protection Of Employees' Rights
}

\author{
Raximov Miryoqub Aktamovich \\ Teacher Of Tashkent State University Of Law Tashkent, Uzbekistan
}

Journal Website:

http://usajournalshub.c

om/index,php/tajpslc

Copyright: Original

content from this work

may be used under the

terms of the creative

commons attributes

4.0 licence.

\section{ABSTRACT}

This article is devoted to the analysis of ways to protect the labor rights and interests of employees by the legislation of the Republic of Uzbekistan. The author identifies issues that arise when employees implement state guarantees of labor rights and freedoms. Measures aimed at the most effective protection of the rights and interests of employees are proposed.

\section{KEYWORDS}

Labor rights, self-defense, judicial protection, collective agreements, social partnership, mediation, international labor organization, trade unions, labor control.

\section{INTRODUCTION}

The pandemic not only exposed weaknesses in the global labor market, but also revealed gaps in the social protection system, especially among migrants and the informally employed. During the pandemic, the labor market in Uzbekistan is under huge pressure due to the growing number of unemployed. If we pay attention to the figures, the number of employed increased 1.5 times (from 8.8 million to 13.5 million), the number of employers increased 4.5 times (from 203.2 thousand to 928.9 thousand) [1]. According to the Ministry of employment and labor relations 600-700 thousand people enter the labor market of Uzbekistan every year, and the number of jobs created is up to 500 thousand. Two hundred more are missing. The total labor force in the country (men 16-59 years old and women 15-54 
years old) is 19 million people. Of these, 5.1 million are employed unofficially, and about two million work abroad [2]. First Deputy Minister of employment and labor relations said that almost 400,000 businesses have temporarily stopped operating or reduced their workloads due to the impact of the coronavirus. Due to the strict isolation of the country, about 150 thousand workers were forced out of work, about 498 thousand citizens returned to their Homeland, labor migrants without a permanent income, and more than 200 thousand families are below the poverty line [3].

\section{Stages of development of labor legislation in Uzbekistan.}

The Labor code of the Republic of Uzbekistan was adopted on December 21, 1995. and entered into force on April 1, 1996. It should be noted that this was the first Labor code adopted in the former Soviet Union. This Code abolished a significant number of norms, the very existence of which was associated with the monopoly of state property, eliminated many declarative provisions contained in the previous Labor Code. And it significantly expanded the scope of collective-contractual and individual-contractual regulation of labor relations, provided the creation of legal bases for the development of social partnership in the field of labor, solved a set of other issues necessary for the formation and development of the labor market, improved mechanisms for ensuring and protecting the labor rights of employees.

According to Labor Code everyone is guaranteed protection of labor rights, which is carried out by the bodies of supervision and control over compliance with labor legislation, as well as by the bodies for consideration of labor disputes. Monitoring and supervision of compliance with labor legislation and labor protection rules is carried out by specially authorized state bodies and their inspections, trade unions.

Another special normative act is e Law of the Republic of Uzbekistan "On Mediation" was adopted by the Legislative Chamber on June 12, 2018 and approved by the Senate on June 28, 2018. The law came into force on January 1 , 2019. In Uzbek legal system generally mediation in considered as new part of alternative dispute resolution instrument in labor disputes. That is why, it is infancy and not popular. Most disputes in general and labour disputes in particular reach the courts [4].

At the same time, it should be noted that in the more than twenty years since the adoption of the labor code, significant changes have taken place in the social, economic and other spheres of public life in Uzbekistan, which determine the need for new approaches, bringing the model of legal regulation of labor and directly related social relations in line with modern realities.

Unfortunately, the changes and additions that were made to the Labor code after its adoption did not solve a significant number of existing problems. The current Labor Code of the Republic of Uzbekistan does not promote the introduction of modern forms of employment, professional training systems, in particular, the development of entrepreneurship, in particular, the requirements approved in The strategy of action on five priority areas of development of the Republic of Uzbekistan in 2017-2021, does not reflect new means of regulating labor relations.

Taking into account the above, the government developed a draft law "On approval of the Labor Code of the Republic of Uzbekistan" with the participation of relevant ministries and organizations. The draft of Labor code in the new edition consists of 2 
parts, 34 chapters and 621 articles. The main aspect of the bill is that it has the feature of working directly, and does not require the adoption of additional legislative acts. Taking into account the pandemic of COVID-19, it is planned to introduce norms that determine the possibility of giving the employee a leave with a partial salary, but not less than the minimum wage, and also impose an unpaid leave for up to 6 months.

\section{Characteristic features of the labor legislation of the Republic of Uzbekistan on the protection of workers ' rights}

The specificity of labor relations is manifested in the fact that they clearly show both common and contradictory interests of their parties. On the one hand, both the employee and the employer are vitally interested in continuing the employment relationship, since it is a condition of their existence. It is the labor relationship that allows its parties to achieve their goals: the employer-to make a profit, and the employee to receive payment for their work. On the other hand, it is important to emphasize that the goals of the subjects of labor relations are different. The employer strives to extract the maximum profit at the minimum cost, including the cost of wages, improving working conditions, etc. The employee, on the contrary, is interested in increasing wages, improving working conditions, reducing working hours, etc.

It is necessary to socialize the remaining employees who insist on cancellation due to the pandemic and to form a legal framework reflecting the procedure for granting privileges and preferences to employers by the state [5].

The formation of labor law as a branch of law was influenced by two fundamental factors:

firstly, state intervention in the legal regulation of labor relations, the search for the optimal combination of private and public law methods of regulation;

secondly, development of collective and contractual regulation of labor relations.

As noted above, application to the industrial relations mechanism the usual civil transactions of material nature have resulted in de facto inequality between employer and employee, to the fact that the latter could dictate to the employee in almost any conditions to which the worker was forced to agree for fear of losing their jobs, and therefore livelihoods. The working conditions of employees were so difficult that it created a threat of social conflicts and required state intervention. It is for this reason that in the XIX century there are laws regulating labor relations and limiting the arbitrariness of employers.

Social partnership has begun to play a significant and growing role in the mechanism of legal regulation of social relations in the sphere of hired labor. Collective bargaining and the conclusion of collective agreements and agreements have been developed both at the enterprise level and at the territorial (regional), sectoral and national levels.

A General agreement which the main document of the social partnership was adopted between the Cabinet of Ministers of the Republic of Uzbekistan, the Council of the Federation of trade unions of Uzbekistan, the Confederation of employers of Uzbekistan on socio-economic issues for 2020-2022. This document includes a number of measures aimed at solving socio-economic issues. For example it reflects the issues of labor remuneration, raising incomes and living standards of the population. As well as giving special attention for paying to the prevention of injuries and occupational diseases, monitoring the state of working conditions in 
the workplace, and developing standards of requirements and standards for labor protection in agriculture [6]. It should be note that the idea of tripartism is also based on the work of the ILO, where labor issues are resolved on a tripartite basis by delegations from state governments, trade unions and entrepreneurs.

\section{Functions of labor law.}

The functions of law are understood as objectively necessary, the main directions of legal influence on public relations, expressing the essence of law and its social purpose. Depending on the scope of the function of law is divided into:

- General law (common to all branches of law);

- Intersectoral, inherent in two or more (but not all) branches of law;

- Sectoral - typical for a given branch of law;

- The functions of individual norms of law that have a specific focus associated, for example, with the action of prohibiting norms in criminal law, incentive norms in labor law, binding norms in administrative law, etc.

In the general theory of law, it is customary to distinguish between general social and special legal functions of law.

General social functions reflect the directions of the impact of law as a social regulator of relations in various spheres of public life. The general social functions include: economic, political, educational, cultural and historical, informational functions of law, and the function of social control.

Regulatory and protective functions are special legal functions of law. The regulatory function of law is a direction of legal impact, consisting in establishing general rules of behavior, granting subjective rights and imposing legal obligations on subjects of law in order to consolidate and develop positive social relations.

The production function is reflected in those provisions of labor legislation that provide for the effective functioning of the labor market, the economic feasibility of using hired labor, which allows the employer to make a profit by increasing labor efficiency, strengthening discipline, etc.

The protective function is implemented in the provisions of labor legislation aimed at ensuring and protecting the rights of employees, preventing the arbitrariness of the employer, legislative consolidation of a minimum level of rights and guarantees for employees, mandatory for all employers, ensuring labor protection and improving working conditions, etc. We can see protective function of labor law in judicial cases. If we pay attention to the data for 2019 year, a total of 4 233 cases of labor disputes have been carried out by the courts, of which 1279 are connected with the payment of wages. In the general account, disputes related to the payment of wages accounted for more than 30 percent of all labor disputes [7].

It should be noted that it would be a mistake to look for a balance of the production and protective functions of labor law in each of its norms. Some norms may give priority to the interests of the employer, others to the interests of the employee, but in general a balance of production and protective functions must be ensured. Thus, the main functions of labor law are the production and protection functions. The need to ensure a balance of these functions stems from the very nature of the labor relationship and is due to the social purpose of labor law.

General characteristics of the system of social relations which regulated by labor law. 
Labor law, as is evident from the name of this industry, is designed to regulate social relations associated with labor. However, not all of these relationships are governed by labor law.

Firstly, independent work that is not based on the conclusion of an employment contract, and therefore not related to employment, is not regulated by labor law. For example, relations related to the independent work of an individual entrepreneur, writer, artist, or composer are not included in the subject of labor law. Labor law regulates social relations that arise on the basis of an employment contract concluded between an employee and an employer. Such relations are usually called relations of hired, non-independent labor, and in international legal acts the term "dependent" labor is used. This approach to the characterization of the work under consideration is explained by the fact that the owner of the labor force (employee) who wants to go to work is distant from the means of production and tools owned by the employer.

Secondly, the relations that develop in the process of hired labor are traditionally divided into two groups in the science of labor law. The first group includes relations related to the technical organization of labor. These relations are fixed in the relevant technical regulations. However, in the process of carrying out labor activities, people are not only in certain relationships that develop in connection with their impact on the nature and objects of labor.

The second group is formed by strong-willed social relations arising between an employee and an employer on the basis of an employment contract regarding the employee's personal performance for remuneration of work in a certain labor function (specialty, qualification or position) with the employee's subordination to the internal labor schedule on the terms established by the agreement parties, legislative and other normative acts on labor.

\section{Characteristic features of the employment relationship}

Revealing the characteristic features of an employment relationship allows us to identify its specifics, to distinguish it from relations that are the subject of other branches of law and to one degree or another related to labor, in particular, from relations arising on the basis of a conclusion between a customer and an individual-the executor of civil contracts. The characteristic features of an employment relationship are followings:

Performance by an employee of work for a specific labor function. It should be paid attention to the fact that civil law relations arising on the basis of the above contracts are formed in relation to the final materialized result of an individually defined task or service. In the labor legal relationship, the labor process itself is regulated. An employee is obliged to perform any work within the framework of the specialty, qualification or position that is stipulated in the employment contract and specified in the list of job duties contained in the job description.

Personal performance by the employee of the labor function stipulated by the employment contract. The employee is obliged to personally perform the work specified in the employment contract in a certain specialty, qualification or position. He does not have the right to entrust the performance of this work to someone else or involve other persons for its performance. Thus, in contrast to legal relations arising from contracts of a civil nature, an employee who is in an employment relationship with an employer personally performs work in a certain specialty, qualification or position. 
The presence of an element of subordinate power in the employment relationship. In an employment relationship, the equality of the parties to an employment contract is combined with the employee's subordination to the employer's economic authority. The employee is obliged to comply with the internal labor regulations. Equality of the parties, which is characteristic of civil relations, is also characteristic of labor relations. It is manifested, in particular, in the fact that the employment relationship arises on the basis of the mutual will of the employee and the employer, the terms of the employment contract. At the same time, the implementation of joint labor activities by employees objectively requires the organization of the labor process, ensuring labor management. The element of subordination, which means subordination of one side of the employment relationship (employee) to the other (employer), distinguishes it from civil relations, the parties of which are equal.

Special character remuneration. One of the main feature of the labor relationship is that its payable which is carried out through the remuneration of the employee, the regulation of which is based both on private law (characteristic of civil law) and on public law methods. The characteristic features of remuneration, in contrast to remuneration in civil law relations, are: the establishment by the state of the minimum wage; regulation of the frequency of its payment - at least once every fortnight; determination of the place of payment of wages; limitation of deductions from wages

The inclusion of an employee in the workforce of the enterprise. Consequently, all employees who have entered into an employment contract are included in the labor collective of the enterprise with which they have an employment relationship. They are subject to the collective agreement, as well as the collective agreement and other local acts of the enterprise. Persons performing one-time tasks (work) under contracts of a civil nature are not members of the labor collective of the enterprise, are not vested with rights and do not bear the obligations provided for by the above acts.

Lasting character. The employment relationship is ongoing. This means that it is not limited to the fulfillment of any obligation. The employee must regularly perform the work stipulated by the employment contract, and the employer pays the employee's wages and provides the necessary working conditions. The continuing nature of the labor relationship is manifested in the fact that the subject of the labor contract is the performance of the labor function (regular work), and not the achievement of a specific labor result.

\section{CONCLUSION}

As a result of the above research, we can conclude that, the adoption of the new version of the Labor code will serve to balance the interests of employees and employers, taking into account the requirements of the market economy, attract them to social partnership, and motivate the parties to increase labor productivity. The adoption of this document will also serve to introduce labor legislation in the sphere of small business and individual entrepreneurship, streamline the active development of new forms of attracting citizens to work, and bring the provisions of the Labor code in line with international law, in particular, international treaties ratified by the Republic of Uzbekistan. 
Doi: https://doi.org/10.37547/tajpslc/Volumeo2Issue11-12

\section{REFERENCES}

1. http://parliament.gov.uz/uz/events/co mmittee/31894/?sphrase_id $=6708663$

2. https://uz.sputniknews.ru/economy/20 200926/15060208/Rynok-truda-vUzbekistane-kak-COVID-19-otkrylnovye-vozmozhnosti.html

3. https://mehnat.uz/ru/pages/doklad-natemu-obespechenie-progressa-spomoschyu-preobrazovaniy

4. Raximov, M.A. (2018) "New institution: resolving labour disputes through mediation," Review of law sciences: Vol. 3 : Iss. 1 , Article 11. Available at: https://uzjournals.edu.uz/rev_law/vol3/ iss $1 / 11$.

5. Rakhimov, M.A. (2020) "Features of protecting labor rights of employees in the context of the Covid-19 pandemic." Lawyer herald: 6-2020-2-1 4 (2020) DOI http://dx.doi.org/10.26739/2181-94162020-4-17 Available at: http://yuristjournal.uz/index.php/lawye r-herald/article/view/93/80

6. https://kasaba.uz/ru/o-generalnomsoglashenii-mezhdu-kabinetomministrov-respubliki-uzbekistansovetom-federatsii-profsoyuzovuzbekistana-konfederatsiejrabotodatelej-uzbekistana-posotsialno-ekonomicheskim-voprosamna-20/

7. https://huquqburch.uz/me\%d2\%b3nat\%d2\%b3u\%d2\%9bu\%d2\%9bij-

munosabatlari-nizolar-va-echimlar/ 